Annals of Warsaw University of Life Sciences - SGGW

Horticulture and Landscape Architecture No 39, 2018: 49-53

(Ann. Warsaw Univ. of Life Sci. - SGGW, Horticult. Landsc. Architect. 39, 2018)

DOI 10.22630/AHLA.2018.39.5

\title{
Morphological changes and micronuclei frequency in microspore tetrads of Achillea millefolium from the areas of coal-fired power plants
}

GRAŻYNA OBIDOSKA, EDYTA NAGÓRSKA, AGNIESZKA NADULSKA

Faculty of Horticulture, Biotechnology and Landscape Architecture, Warsaw University of Life Sciences - SGGW

\begin{abstract}
Morphological changes and micronuclei frequency in microspore tetrads of Achillea millefolium from the areas of coal-fired power plants. In Poland the energy sector is $80 \%$ based on coal and lignite, therefore the problems associated with air pollution by fuel combustion by-products are of great importance. Carbon and sulphur dioxides, polycyclic aromatic hydrocarbons, dioxins, furans and heavy metals such as cadmium and mercury have a significant effect on ambient air quality, influencing human health and the state of ecosystems. The aim of the research was to evaluate the effect of two coal-fired power plants in Warsaw on vegetation in their vicinity. Achillea millefolium was selected as a representative bioindicating species, because of its high phytosociological constancy in the two power plant areas and its relatively high c-DNA value. Morphological and cytogenetic changes were observed, indicating the adverse effect of a power plant on the vegetation in its central area and close vicinity, potentially leading to gradual degradation and adverse landscape changes.
\end{abstract}

Key words: power plants, Achillea millefolium, morphological changes, genotoxicity

\section{INTRODUCTION}

In Poland the energy sector is $80 \%$ based on coal and lignite (PAIiIZ 2013), therefore the problems associated with air pollution by fuel combustion by-products are of great importance. Carbon and sul- phur dioxides, polycyclic aromatic hydrocarbons (PAHs), dioxins, furans and heavy metals such as cadmium and mercury have a significant effect on ambient air quality, influencing human health and the state of ecosystems. In the 1980s the pollution emitted from Polish and German coal-fired power plants (Zygmunt et al. 1985) caused the total destruction of spruce forests in south-western Poland (Kamiński 1985), changing totally the landscape of e.g. the Izerskie Mountains. Presently in Europe the ambient air quality has highly improved and such visible destructions are rare, but heavy metals, PAHs, nitrogen oxides and secondary pollutants such as ozone, may still seriously affect the growth and reproduction of natural and semi-natural vegetation, especially in high-risk urban and industrial areas.

The aim of the research was to evaluate the effect of two coal-fired power plants in Warsaw on vegetation in their vicinity. Achillea millefolium was selected as a representative species, because of its high phytosociological constancy in the two power plant areas and relatively high c-DNA value (Obidoska et al. 2005). 


\section{MATERIAL AND METHODS}

The location of the research was two Warsaw power plants: Siekierki and Żerań. Observations of $A$. millefolium were made at two check points: one situated in the central part of each power plant and one in its close eastern vicinity, about $1 \mathrm{~km}$ from their smokestacks. The second location was dictated by the dominating wind direction (the majority of winds in Poland are from a westerly direction). First the morphological aberrations such as: abnormal inflorescences, deformed ligulate flowers and thin, tangled shoots were observed. Secondly we searched for cytogenetic abnormalities; micronuclei in microspore tetrads. For this purpose inflorescences in appropriate stage were gathered, fixed in Carnoy's solution and stored in $70 \%$ ethanol. For microscopic slide preparation, anthers were isolated, stained and squashed under a cover glass. Micronuclei were scored in 900 microspore tetrads per check point. The control A. millefolium originated from the unpolluted Mazurian district. Results were subjected to a one way analysis of variance and the Tukey test with the statistical significance set at $P=0.05$.

\section{RESULTS AND DISCUSSION}

In situ biomonitoring may be based on behavioural measurements or survival, growth, genomics or other metrics (Gerhardl 1999). In the case of our research, morphological changes and cytogenetic aberrances in the bioindicating species Achillea millefolium were observed. Morphological and cytogenetic changes were noted in both the investigated coal fired power plants' sites. The shoots were thin and tangled in 60 to over $90 \%$ of the sampled plants, and deformations occurred in the inflorescences structure and in ligulate flowers (Fig. 1). Aberrations were especially visible in specimens found in the central parts of both areas, where the smokestacks were located; however, pollution emitted by smokestacks is normally distributed at a distance. The probable reason for the

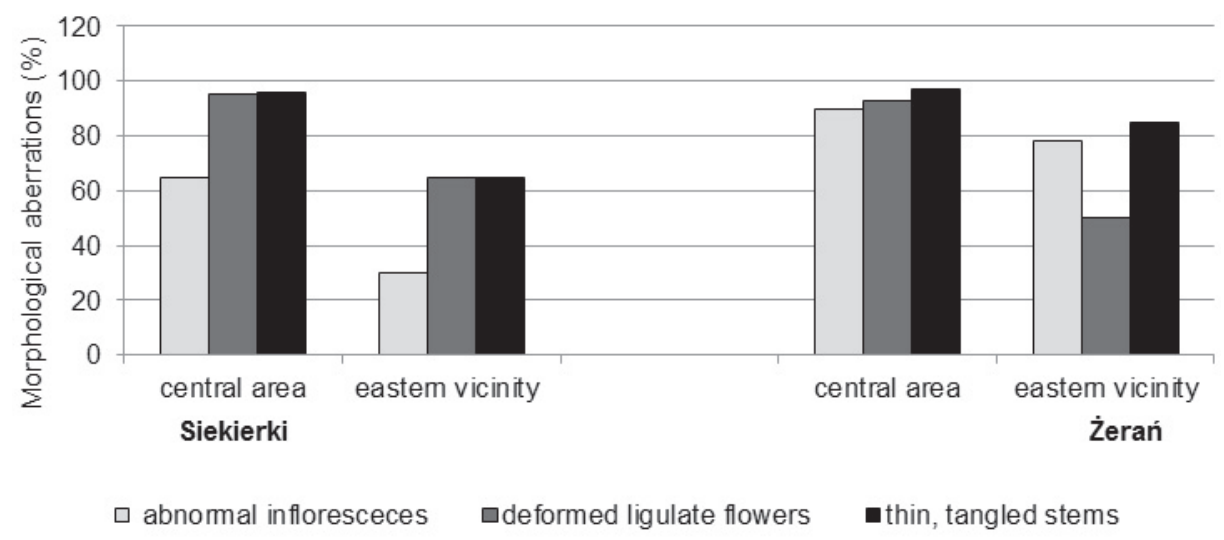

FIGURE 1. Influence of coal-fired power plants on morphological features of Achillea millefolium growing in their central parts or in close eastern vicinities 
results was the presence of coal piles in the central parts of both areas. They produce dust and leachate, contaminating the soil and groundwater with sulphates and metals such as chromium, cadmium or lead (Denham and Nichols 1995).

The close eastern vicinities of the power plants seemed to be less polluted, because the combustion products such as polycyclic aromatic hydrocarbons (PAHs), nitric oxides ( $\mathrm{NO}_{\mathrm{x}}$ ) and sulphur dioxide $\left(\mathrm{SO}_{2}\right)$ (Chung-Yih et al. 2005) and mercury (Blanvillain et al. 2007) are deposited at a further distance from the source, influencing ecosystems situated kilometres away. For example in the case of the Płock refinery (Karaczun et al. 2008, Indeka et al. 2009) the PAH content in soils was highest at 1 and $6 \mathrm{~km}$ distances, in an eastern direction, according to the prevailing winds.

A genonotoxic effect was also detected in the bioindicators (Fig. 2). In the central parts of both power plants' areas, the number of micronuclei, scored in early tetrads after the meiosis of pollen mother cells, was significantly higher in comparison with the control. Similar effects were observed in a power plant area in India, especially in the sites located near the ash pond and the ash dumping places (Ghosh et al. 2012). In the close eastern vicinities of both power plants the effect diminished and the frequencies of $\mathrm{MCN}$ were not statistically significant in comparison with the control. The toxic and genotoxic effect in Achillea millefolium was more intensive in the Żerań than in the Siekierki power plant area.

The evaluated effects are of course not visible on the landscape scale, but they provide evidence for the negative influence of power plants' pollution, potentially leading to the gradual degradation of vegetation within their area and vicinity.

\section{CONCLUSIONS}

1. Pollution caused by coal-fired power plants may affect native vegetation within their area and in the vicinity.

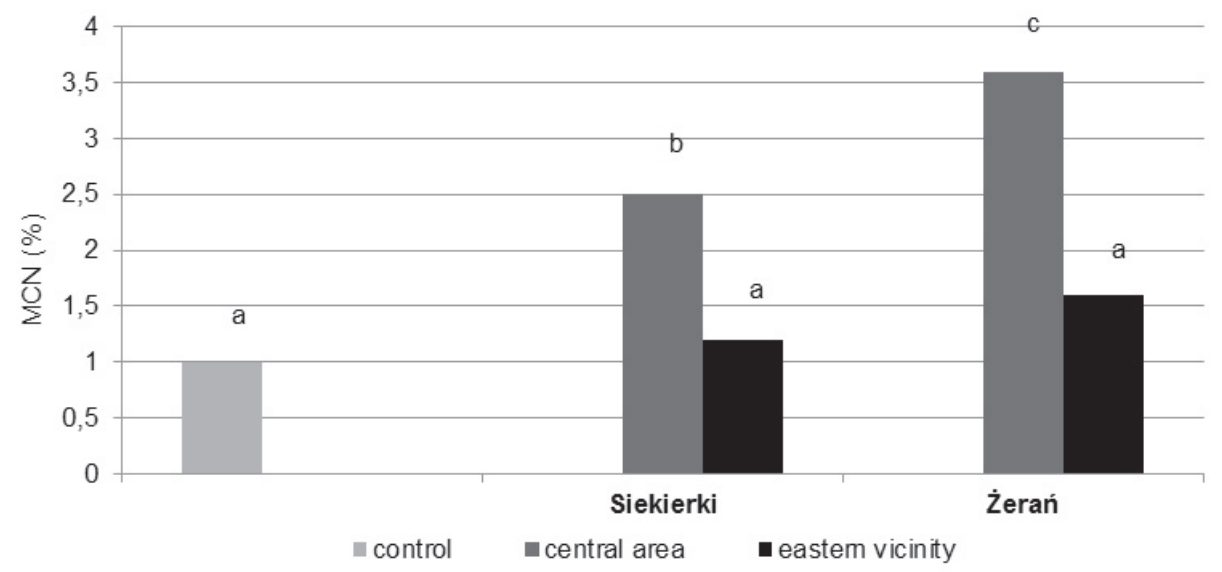

FIGURE 2. Influence of coal-fired power plants on micronuclei frequency (MCN) in microspore tetrads of Achillea millefolium growing in their central parts or in close eastern vicinities (means with the same letter do not differ significantly) 
2. Within the two examined powerplant areas, and to a lower extent in their close vicinities, morphological changes were observed in the selected bioindicator species Achillea millefolium.

3. The genotoxic effect, micronuclei in microspore tetrads, appeared only within the power plants' areas.

4. Close vicinities seemed to be moderately polluted, but the combustion products from the smokestacks are normally deposited at a further distance from the source, potentially influencing ecosystems situated kilometres away.

5. Results indicate the negative influence of coal-fired power plants on vegetation, potentially leading to its gradual degradation posing the risk of adverse landscape changes.

\section{REFERENCES}

BLANVILLAIN G., SCHWENTER J.A., DAY R.D., POINT D. 2007: Diamondback terrapins, Malaclemys terrapin, as sentinel species for monitoring mercury pollution of estuarine systems in south Carolina and Georgia, USA. Toxicol. Chem. Oxford 26 (7): 1441-1450.

CHUNG-YIH K., HSIN-HONG C., JENG-FU S., RUEY-HONG W. 2005: Variations of nitrate and sulphate in the atmosphere on days of high and low particulate matters. Toxicol. Chem. Oxford 24 (4): 846-851.

DENHAM M.E., NICHOLS R.L. 1995: The speciation of groundwater contaminated with coal pile leachate at the Savannah river site, South Carolina. Document prepared for International Association of Hydrogeologist Congress - Solutions. Edmonton, Alberta 04-10.06.1995.

GERHARDLA. 1999: Biomonitoring for the 21st century. In: A. Gerhardl (Ed.) Bio- monitoring of polluted water. Reviews on actual topics. Environ. Res. Forum 9: $1-13$.

GHOSH S., CHATTERIEE T., SAHA T., MUKHERIEE A. 2012: Genotoxicity assessment of soil contamination: a case study from the Farakka coal-fired plant in eastern India. The Nucleus 55 (1): 45-50.

INDEKA L., KARACZUN Z., OBIDOSKA G. 2009: Soil concentration of selected polycyclic aromatic hydrocarbons around the Petrochemical Plant in Płock in 1987-2006. Ann. Warsaw. Univ. Life Sci. - SGGW. Land Reclam. 41: 11-17.

KAMIŃSKI E. 1985: Ekofizjologiczne aspekty zamierania lasów z powodu zanieczyszczenia atmosfery tlenkami siarki i azotu. Las Polski 15-16: 5-7.

KARACZUN Z.M., OBIDOSKA G., INDEKA L. 2008: Evaluation of the effect of proecological investments in the Petrochemical Plant in Płock on heavy metals content in soils and agricultural products in the vicinity area. Ecol. Chem. Eng. 15: 31-36.

OBIDOSKA G., SADOWSKA A., NADULSKA A. 2005: Attempt to select native flora species suitable for in situ monitoring of environmental genotoxicity. Ann. Warsaw Agricult. Univ. - SGGW. Horticult and Landsc. Arch. 26: 13-18.

PAIiIZ 2013: Sektor energetyczny w Polsce. Profil sektorowy. DIG, Polska Agencja Informacji i Inwestycji Zagranicznych S.A.

ZYGMUNT K., JASTRZĘBSKA M., LISOWSKI A., KORCZOWSKI J., MASAKOWSKA G. 1985: Skutki emisji pyłów i gazów przemysłowych na stan zanieczyszczenia atmosfery $\mathrm{w}$ rejonie Worka Żytawskiego. In: Węzłowe problemy inżynierii środowiska w Makroregionie Południowo-Zachodnim. NOT, Jelenia Góra: 24-30.

Streszczenie: Zmiany morfologiczne i częstość wystepowania mikrojader $w$ tetradach mikrospor u Achillea millefolium $z$ terenów elektrociepłowni 
opalanych weglem. W Polsce sektor energetyczny w $80 \%$ oparty jest na spalaniu węgla kamiennego i brunatnego, dlatego problemy związane $\mathrm{z}$ zanieczyszczeniem powietrza substancjami emitowanymi przy spalaniu tego typu paliw są dla nas bardzo istotne. Dwutlenek węgla i siarki, wielopierścieniowe węglowodory aromatyczne, dioksyny i furany oraz metale ciężkie, takie jak kadm i rtęć, mają negatywny wpływ na jakość powietrza, od której istotnie zależą zdrowie ludzi i stan ekosystemów. Celem badań była ocena wpływu dwóch opalanych węglem warszawskich elektrociepłowni na roślinność w ich sąsiedztwie. Gatunek Achillea millefolium został wybrany jako wskaźnikowy ze względu na znaczną stałość fitosocjologiczną na terenach obu elektrociepłowni oraz relatywnie dużą wartość c-DNA. Zaobserwowano zmiany morfologiczne i cytogenetyczne wskazujące na negatywne oddziaływanie elektrociepłowni na szatę roślinną na ich terenie oraz w bezpośrednim sąsiedztwie, potencjalnie prowadzace do sukcesywnej degradacji i niekorzystnych zmian w krajobrazie.

Stowa kluczowe: elektrownia, Achillea millefolium, zmiany morfologiczne, genotoksyczność

MS received: 02.10 .2017

MS accepted: 13.07.2018

Authors' address:

Grażyna Obidoska

Katedra Ochrony Środowiska

Wydział Ogrodnictwa, Biotechnologii

i Architektury Krajobrazu

Szkoła Główna Gospodarstwa Wiejskiego

w Warszawie

ul. Nowoursynowska 166, 02-787 Warszawa

e-mail: grazyna_obidoska@sggw.pl 